\title{
First record of Tigrisoma fasciatum (Such, 1825) (Aves: Ardeidae) in the State of Amapá, Brazil and updated species distribution in Central and South America
}

\author{
Lia Nahomi Kajiki, ${ }^{1,2}$ Cintia Massumi Togura ${ }^{1}$ \& Fernanda Michalski \\ ${ }^{1}$ Laboratório de Ecologia e Conservação de Vertebrados - PPG em Biodiversidade Tropical, \\ Universidade Federal do Amapá - UNIFAP, Campus Universitário Marco Zero, \\ Rod. Juscelino Kubitscheck, Km 02, CEP 68902-280, Macapá, AP, Brasil. http://www2.unifap.br/ppgbio/ \\ ${ }^{2}$ Corresponding author: Lia Nahomi Kajiki, e-mail: lia.nahomi@gmail.com
}

KAJIKI, L.N., TOGURA, C.M. \& MICHALSKI, F. First record of Tigrisoma fasciatum (Such, 1825) (Aves: Ardeidae) in the State of Amapá, Brazil and updated species distribution in Central and South America. Biota Neotrop. (13)4: http://www.biotaneotropica.org.br/v13n4/en/abstract?short-communication+bn02413042013

\begin{abstract}
The Fasciated Tiger-heron (Tigrisoma fasciatum) is considered endangered in Brazil and Argentina. Although this species has a large range in Central and South America, its records are scattered and scarce. We used a combination of searches in the scientific literature and new field records to provide an updated distributional range of this species. Searches for records and photos of $T$. fasciatum were conducted using online databases. We also conducted field surveys along the margins of the Araguari and Falsino rivers, in the National Forest of Amapá, a sustainable protected area in the eastern Brazilian Amazon. Our literature review provided a total of 25 new distributional records of $T$. fasciatum. During our river based surveys we recorded one individual of $T$. fasciatum, which represents an extension of $499 \mathrm{~km}$ from the nearest previously documented occurrence. We present these findings in an up to date distributional map of $T$. fasciatum and highlight the need of further studies in order to better understand the species distribution and ecology.
\end{abstract}

Keywords: avifauna, Amazon region, range extension, FLONA-AP, protected areas.

KAJIKI, L.N., TOGURA, C.M. \& MICHALSKI, F. Primeiro registro do Tigrisoma fasciatum (Such, 1825) (Aves: Ardeidae) no estado do Amapá, Brasil e distribuição atualizada da espécie na América Central e do Sul. Biota Neotrop. 13(4): http://www.biotaneotropica.org.br/v13n4/pt/abstract?short-communication+bn02413042013

Resumo: O socó-boi-escuro (Tigrisoma fasciatum) é uma espécie considerada em perigo de extinção no Brasil e na Argentina. Apesar de possuir extensa distribuição na América Central e do Sul, os registros são esparsos e escassos. Nós usamos uma combinação de buscas na literatura científica e novos registros de campo para fornecer uma distribuição geográfica atualizada dessa espécie. Buscas por registros e fotos de $T$. fasciatum foram realizadas em bancos de dados online. Nós também realizamos buscas de campo às margens dos rios Araguari e Falsino, na Floresta Nacional do Amapá, uma Unidade de Conservação de Uso Sustentável na Amazônia Oriental brasileira. Nossa revisão de literatura forneceu um total de 25 novos registros de distribuição de T. fasciatum. Durante nossas buscas ao longo de rios, nós registramos um indivíduo de T. fasciatum, o que representa uma extensão de 499 $\mathrm{km}$ de sua mais próxima ocorrência documentada anteriormente. Nós apresentamos esses registros em um mapa atualizado da distribuição geográfica de T. fasciatum e enfatizamos a necessidade de mais estudos para a melhor compreensão da distribuição e ecologia da espécie.

Palavras-chave: avifauna, Amazônia, extensão da distribuição, FLONA-AP, unidade de conservação. 


\section{Introduction}

The Fasciated Tiger-heron [Tigrisoma fasciatum (Such, 1825)] is a medium-sized species of tiger-heron distributed throughout Central and South America, with scattered records across its range. It has been recorded in Argentina, Bolivia, Brazil, Colombia, Costa Rica, Ecuador, Panama, Peru and Venezuela (InfoNatura 2007, BirdLife 2009). Although currently listed by the IUCN as Least Concern, it is considered a naturally rare species (Eisenmann 1965, Yamashita \& Valle 1990, Renaudier \& de Guyane 2010, Vallely et al. 2010) and is classified in the high research priority category (Parker III et al. 1996). The current population trend is not known, but it is not believed to be decreasing sufficiently rapidly to approach the thresholds for classification as endangered under the population trend criterion ( $>30 \%$ decline over 10 years or three generations) (BirdLife 2009). However, this species is listed as endangered in Brazil (Straube et al. 2008) and in Argentina (Fraga 1996, López-Lanús et al. 2008).

Current Brazilian red-lists consider $T$. fasciatum as critically endangered in two southeastern states (Andrade 1998, Straube et al. 2008). Straube et al. (2008) observe that the distribution of $T$. fasciatum is poorly documented in Brazil, but locations of this species have been recorded in the Amazon, Atlantic Forest, Cerrado and Pantanal biomes. However, over the past five years new, freely available records have been documented online [see Wikiaves (2013)], through the development and popularization of web based data-sharing tools, such as the Wikiaves site (http://www.wikiaves. $\mathrm{com} /$ ). Yet, these records have not been considered in previous distribution range maps [see databases of InfoNatura (2007) and BirdLife (2009)] or in more recent studies of this species (Pivatto et al. 2006, Faria 2008, Straube et al. 2008). However, these online resources provide a rich source of information that should be used in order to better understand the distributional range of bird species.

The most recent record of the Fasciated Tiger-heron in Brazil was from the state of Rio de Janeiro, municipality of Angra dos Reis (Blanco 2013). The species has also been recently recorded in the Anavilhanas Archipelago in the state of Amazonas (Cintra 2012), contributing to the few records of T. fasciatum in the Amazonian region. Thus, our objective in this study is to present a new record of $T$. fasciatum, which extends the distribution of this poorly known species within the Amazon forest, and to provide a comprehensive review of the current geographic distribution of the species. We also highlight the importance of further studies and conservation efforts in order to better understand the species distribution and ecology.

\section{Material and Methods}

Field data presented here is a subset obtained from surveys along the Araguari and Falsino rivers, which surround the Amapá National Forest ("Floresta Nacional do Amapá", hereafter FLONA-AP), a sustainable-use protected area of 412,000 ha located in northern Amazonia ( $\left.0^{\circ} 55^{\prime} 29^{\prime \prime} \mathrm{N}, 51^{\circ} 35^{\prime} 45^{\prime} \mathrm{W}\right)$ (Figure 1). FLONA-AP is adjacent to continuous undisturbed forests and it is subject to low levels of anthropogenic disturbance (e.g. subsistence hunting) due to the small number of families living on the reserve border (Michalski et al. 2012), maintaining the full community of medium and large sized vertebrates.

From November 2011 to November 2012 we conducted surveys of mid to large sized vertebrates (IBAMA/SISBIO permit number 26653-1) along waterways (Araguari and Falsino rivers) in a motorized boat using a standardized boat census protocol (Pitman et al. 2011). To optimize detections, the boat was piloted along the center of the rivers at a slow speed (mean velocity $\pm \mathrm{SD}=10.3 \pm 3.5 \mathrm{~km} / \mathrm{h}$, range $=2-18$ ). Three to five observers searched for vertebrates on the border of the river, along the adjacent forest canopy, with binoculars. All censuses took place in rainless weather during the morning (08:00-11:59) and afternoon (13:00-18:00), totalizing nine hours per day.

We reviewed the current distribution range of $T$. fasciatum by conducting a literature review and using existing compilations (InfoNatura 2007, Ridgely et al. 2007). We conducted two types of searches (on 20 $0^{\text {th }}$ May 2013) using a combination of the terms 'Fasciated Tiger-heron' and 'Tigrisoma fasciatum' as follows: 1) a literature search in the ISI Web of Knowledge, Scopus, Searchable Ornithological Research Archive and Google Scholar; and 2) a search of photographic records of the species in Google, the Internet Bird Collection (http://ibc.lynxeds.com/), Wikiaves (http://www.wikiaves. com/) and the Visual Resources for Ornithology (http://vireo.ansp. org/). From the total results returned in the searches, we used the following criteria to select the records considered in this study: 1) in order to exclude historical data that could possibly not describe the current distribution range of this species, we only used documents published from 1990 to 2013; 2) we only considered documents that reported an observation of $T$. fasciatum made in the study, excluding documents without a record per se (e.g. documents that mentioned the species, but did not report an observation); and 3) when the document reported a record of $T$. fasciatum, we only considered it if the location of the record fell outside of the area of the distribution range maps provided by InfoNatura (2007) and Ridgely et al. (2007). Therefore, we only included localities not considered by InfoNatura (2007) and Ridgely et al. (2007) in the present distribution range map.

When the document failed to provide geographic coordinates for the record of the species, we used Google Earth (GE) to obtain the most approximate coordinates supported by maps of the study area and key landmarks such as rivers, roads, villages, towns, and other visual features that could be clearly distinguished by GE images.

\section{Results and Discussion}

Surveys resulted in a total of $3,796.2 \mathrm{~km}$ (368.6 hours), including 2,128.9 km (206.7 hours) along the Araguari River, and 1,667.3 km (161.9 hours) along the Falsino River. On 29 April 2012, at $12 \mathrm{~h}$ 48 min (Coordinated Universal Time - UTC-3), we photographed a solitary adult $T$. fasciatum resting on a rock on the margins of the Araguari River (1 ${ }^{\circ} 00^{\prime} 15^{\prime \prime} \mathrm{N}, 51^{\circ} 49^{\prime} 30^{\prime}$ W, Figure 2). The individual was an adult, identified by the rufous lower belly and vent, darker plumage pattern (Perlo 2009), and a relatively short and rather arched culmen (Eisenmann 1965, Martínez-Vilalta \& Motis 1992). As the boat approached the individual, it flew along the river, and perched on a tree branch (Figure 2). Our new record extended the distribution range of the species by $499 \mathrm{~km}$ east-south-east from the nearest documented location in French Guiana (Renaudier \& de Guyane 2010), providing the first documented record of T. fasciatum in the state of Amapá, Brazil (Figure 1).

The literature search returned a total of 61 results, but we considered only the 36 documents, among reports and scientific papers that met our search criteria. From these sources a total of 25 records of T. fasciatum (Table 1) were added to the present distribution range map (Figure 1).

Although not included in any contemporary distribution map (InfoNatura 2007, BirdLife 2009, Perlo 2009), the species has also been recently documented in Suriname (Ottema 2002, Ribot 2013), Guyana (Barnett et al. 2002, Mistry et al. 2008), French Guiana (Renaudier et al. 2010, Renaudier \& de Guyane 2010), Honduras (Vallely et al. 2010), as well as in new localities in Brazil and Peru (Pivatto et al. 2006, Pratolongo et al. 2007, Becker 2008, Faria 2008, Menegheti 2008, Blásquez et al. 2009, Paiva 2009, Garcia 2010, Lane 2010, Cavaretto 2011, Reijnders 2011, Cintra 2012, López 2012, Blanco 2013). These records occurred in regions that share some 


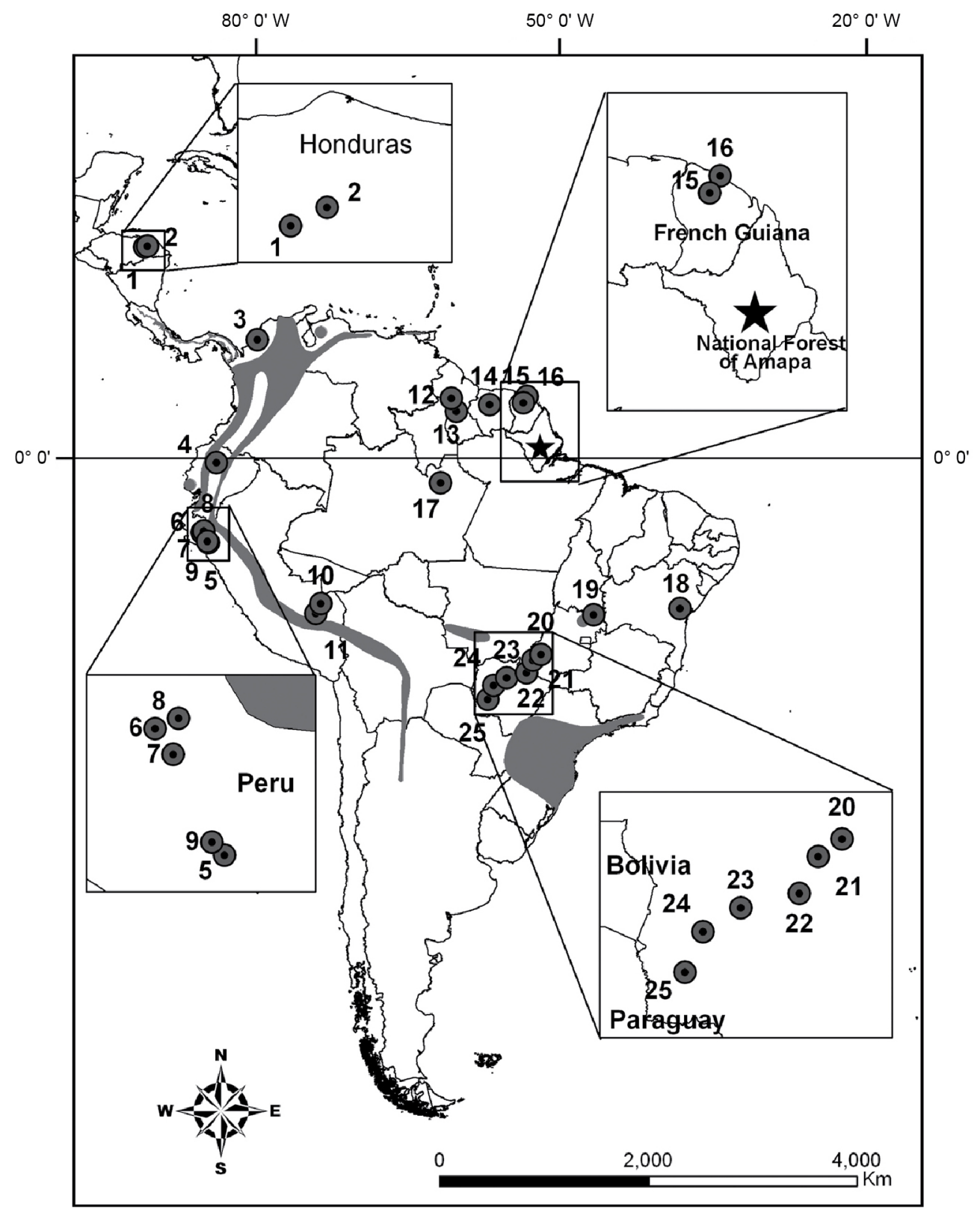

Figure 1. Current distributional map of Tigrisoma fasciatum. The light gray area corresponds to Ridgely et al. (2007) records in Central and South America. The most recent records in Brazil (Pivatto et al. 2006, Becker 2008, Faria 2008, Menegheti 2008, Blásquez et al. 2009, Paiva 2009, Garcia 2010, Cavaretto 2011, Cintra 2012, López 2012), Peru (Pratolongo et al. 2007, Lane 2010, Reijnders 2011), Ecuador (Becker \& Lanús 1997, Vogt 2007), Colombia (Estela \& López-Victoria 2005), Guyana (Barnett et al. 2002, Mistry et al. 2008), French Guiana (Renaudier et al. 2010, Renaudier \& de Guyane 2010), Suriname (Ottema 2002, Ribot 2013) and Honduras (Vallely et al. 2010) are labeled with gray circles. The nearest documented location to our new record (star) is located in French Guiana.

habitat characteristics, such as the proximity to waterbodies (rivers and tributaries), and a hilly topography or an elevational gradient. The reported habitat type along the rivers where T. fasciatum has been documented included a variety of native vegetation types such as savanna, tropical lowland forest and wetland vegetation types (Yamashita \& Valle 1990, Pivatto et al. 2006, Mistry et al. 2008), mangrove forests (Estela \& López-Victoria 2005) and montane and premontane moist forests (Eisenmann 1965, Becker \& Lanús 1997).

The new locality of our field record supports Eisenmann's (1965) first notes on the species habitat characteristics, which highlights that T. fasciatum is thought to have relatively specific habitat requirements preferring riparian areas with waterfalls and rocky outcrops in fast- flowing waters with dense forests along the margins (Eisenmann 1965, Sick 1997, Straube et al. 2008). This type of habitat is discontinuous and scarce (Yamashita \& Valle 1990) and habitat loss caused by deforestation, construction of hydroelectric dams, and pollution of rivers are thought to be the main threats to the species (Yamashita \& Valle 1990, Straube et al. 2008).

For over two decades the scientific literature has highlighted that the main threat to T. fasciatum is the construction of hydroelectric dams as opposed to deforestation (Yamashita \& Valle 1990). Our record representing a major range extension highlights how the Amazon region remains poorly studied even for large easy-to-detect vertebrates. Additionally, our finding highlights the urgent need 
Table 1. Records obtained from the literature review that fell outside the current published distributional range of Tigrissoma fasciatum (InfoNatura 2007, BirdLife 2009).

\begin{tabular}{|c|c|c|c|}
\hline ID & References & Locality & Country \\
\hline 1 & Vallely et al. (2010) & $15^{\circ} 20^{\prime} 52^{\prime \prime} \mathrm{N}, 85^{\circ} 14^{\prime} 51^{\prime \prime} \mathrm{W}$ & Honduras \\
\hline 2 & Vallely et al. (2010) & $15^{\circ} 26^{\prime} 6^{\prime \prime} \mathrm{N}, 85^{\circ} 03^{\prime} 56^{\prime \prime} \mathrm{W}$ & Honduras \\
\hline 3 & Estela \& López-Victoria (2005) & $09^{\circ} 23^{\prime} 4^{\prime \prime} \mathrm{N}, 75^{\circ} 45^{\prime} 21.31^{\prime \prime} \mathrm{W}$ & Colombia \\
\hline 4 & Vogt (2007) & $0^{\circ} 17^{\prime} 58^{\prime \prime} \mathrm{S}, 78^{\circ} 33^{\prime} 12^{\prime \prime} \mathrm{W}$ & Ecuador \\
\hline 5 & Pratolongo et al. (2007) & $06^{\circ} 24^{\prime} 0 " \mathrm{~S}, 79^{\circ} 21^{\prime} 0$ "” W & Peru \\
\hline 6 & Pratolongo et al. (2007) & $05^{\circ} 35^{\prime} 0 " \mathrm{~S}, 79^{\circ} 48^{\prime} 0$ " $\mathrm{W}$ & Peru \\
\hline 7 & Pratolongo et al. (2007) & $05^{\circ} 45^{\prime} 0 " \mathrm{~S}, 79^{\circ} 41^{\prime} 0^{\prime \prime} \mathrm{W}$ & Peru \\
\hline 8 & Pratolongo et al. (2007) & $05^{\circ} 31^{\prime} 0 " \mathrm{~S}, 79^{\circ} 39^{\prime} 0^{\prime \prime} \mathrm{W}$ & Peru \\
\hline 9 & Pratolongo et al. (2007) & $06^{\circ} 19^{\prime} 0 ” \mathrm{~S}, 79^{\circ} 26^{\prime} 0^{\prime \prime} \mathrm{W}$ & Peru \\
\hline 10 & Lane $(2010) *$ & $11^{\circ} 49^{\prime} 8^{\prime \prime} \mathrm{S}, 70^{\circ} 46^{\prime} 26^{\prime \prime} \mathrm{W}$ & Peru \\
\hline 11 & Reijnders $(2011) * *$ & $12^{\circ} 35^{\prime} 0$ " S, $71^{\circ} 14^{\prime} 51^{\prime \prime} \mathrm{W}$ & Peru \\
\hline 12 & Barnett et al. (2002) & $05^{\circ} 10^{\prime} 0^{\prime \prime} \mathrm{N}, 59^{\circ} 28^{\prime} 0^{\prime \prime} \mathrm{W}$ & Guyana \\
\hline 13 & Mistry et al. (2008) & $04^{\circ} 05^{\prime} 0 ” \mathrm{~N}, 59^{\circ} 02^{\prime} 0 ” \mathrm{~W}$ & Guyana \\
\hline 14 & Ribot (2013) *** & $04^{\circ} 40^{\prime} 27^{\prime \prime} \mathrm{N}, 56^{\circ} 10^{\prime} 50^{\prime \prime} \mathrm{W}$ & Surinam \\
\hline 15 & Renaudier et al. (2010) & $04^{\circ} 49^{\prime} 22^{\prime \prime} \mathrm{N}, 53^{\circ} 16^{\prime} 35^{\prime \prime} \mathrm{W}$ & French Guiana \\
\hline 16 & Renaudier \& de Guyane (2010) & $5^{\circ} 22^{\prime} 27^{\prime \prime} \mathrm{N}, 52^{\circ} 57^{\prime} 4^{\prime \prime} \mathrm{W}$ & French Guiana \\
\hline 17 & Cintra (2012) & $02^{\circ} 03^{\prime} 0 " \mathrm{~S}, 60^{\circ} 22^{\prime} 0 " \mathrm{~W}$ & Brazil \\
\hline 18 & Blásquez et al. (2009) & $12^{\circ} 44^{\prime} 30^{\prime \prime} \mathrm{S}, 39^{\circ} 34^{\prime} 50^{\prime \prime} \mathrm{W}$ & Brazil \\
\hline 19 & Menegheti (2008) & $13^{\circ} 30^{\prime} 0 " \mathrm{~S}, 47^{\circ} 08^{\prime} 0$ " $\mathrm{W}$ & Brazil \\
\hline 20 & Paiva (2009) * & $16^{\circ} 57^{\prime} 10^{\prime \prime} \mathrm{S}, 51^{\circ} 48^{\prime} 36^{\prime \prime} \mathrm{W}$ & Brazil \\
\hline 21 & $\operatorname{Garcia}(2010) *$ & $17^{\circ} 27^{\prime} 19^{\prime \prime} \mathrm{S}, 52^{\circ} 32^{\prime} 11^{\prime \prime} \mathrm{W}$ & Brazil \\
\hline 22 & $\operatorname{Becker}(2008) *$ & $18^{\circ} 32^{\prime} 5^{\prime \prime} \mathrm{S}, 53^{\circ} 07^{\prime} 20^{\prime \prime} \mathrm{W}$ & Brazil \\
\hline 23 & Cavaretto (2011) * & $18^{\circ} 55^{\prime} 9 ”, \mathrm{~S}, 54^{\circ} 50^{\prime} 37^{\prime \prime} \mathrm{W}$ & Brazil \\
\hline 24 & López (2012) ** & $19^{\circ} 34^{\prime} 56^{\prime \prime} \mathrm{S}, 56^{\circ} 06^{\prime} 11^{\prime \prime} \mathrm{W}$ & Brazil \\
\hline 25 & Pivatto et al. (2006) & $20^{\circ} 45^{\prime} 0^{\prime \prime} \mathrm{S}, 56^{\circ} 42^{\prime} 0^{\prime \prime} \mathrm{W}$ & Brazil \\
\hline
\end{tabular}

*Wikiaves (http://www.wikiaves.com/). **Internet Bird Collection (IBC) (http://ibc.lynxeds.com/). ***Personal website (http://www.surinamebirds.nl).

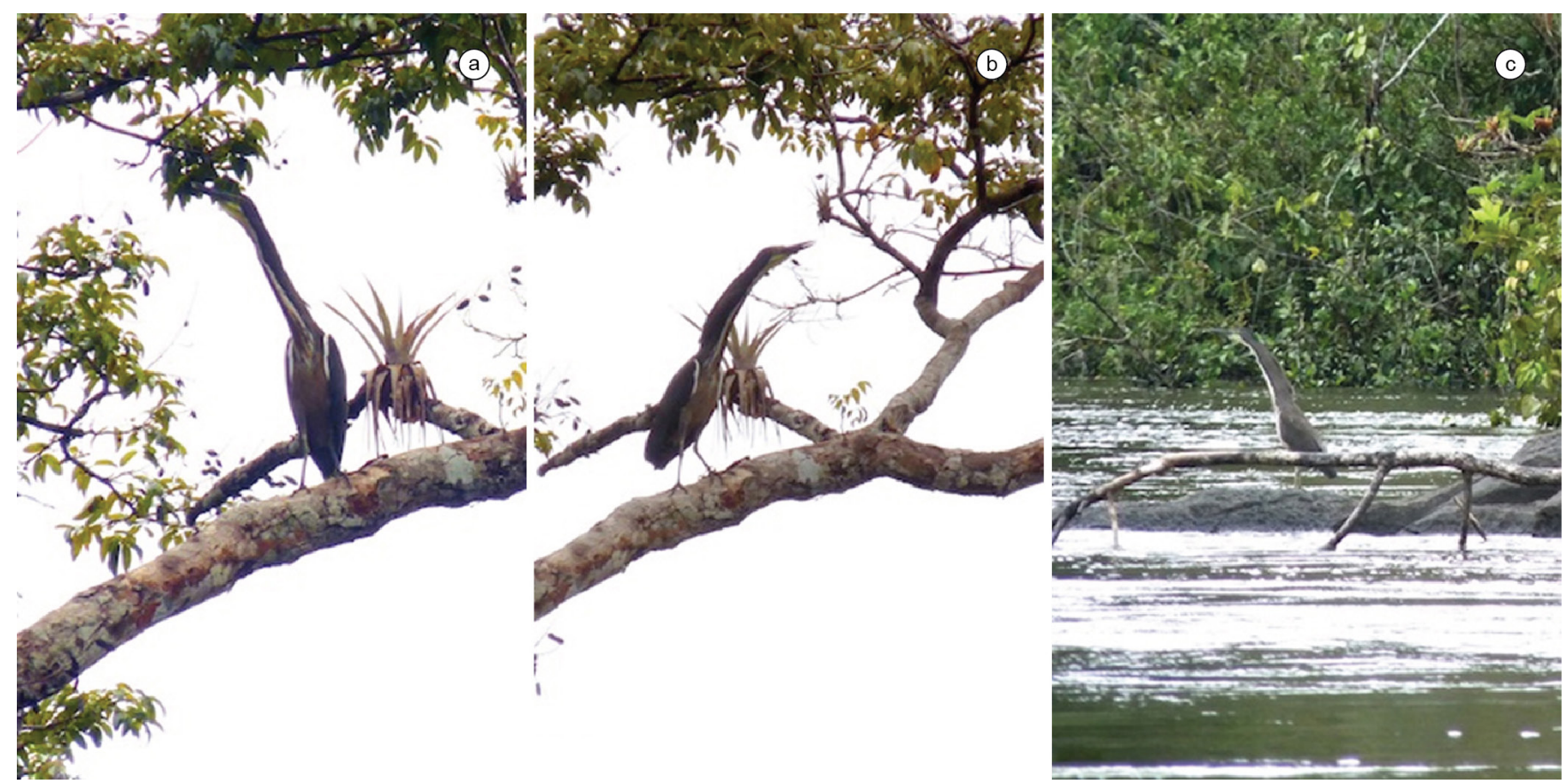

Figure 2. Tigrisoma fasciatum on a tree branch (a-b) and on a rock (c) in the Araguari River, in the National Forest of Amapá (FLONA-AP), state of Amapá, Brazil. Images show details of characteristic plumage patterns and culmen shape. Photos: Lia N. Kajiki, 29 April 2012. 
for future research to provide the basic biological and ecological knowledge of this species necessary to evaluate impacts of anthropogenic actions such as the planned increase in the number of hydroelectric dams (Soito \& Freitas 2011).

The scarcity of T. fasciatum records in Brazil and throughout its geographic range can be attributed to a number of factors, including its secretive habit, aversion to human encounters and perturbations, and restriction to riparian areas (Sick 1997, Straube et al. 2008). Our new record obtained in the field is a good case in point. Although more than $70 \%$ of the state of Amapá is covered by areas with some form of legal protection (Conservação... 2009), the species had never been recorded by any previous study in the state (Coltro 2006, 2008, Souza et al. 2008, Aguiar et al. 2010, Aguiar \& Naiff 2010, Boss \& Aguiar 2011). Another important case to be highlighted is the recent record in the state of Rio de Janeiro (Blanco 2013). The region is considered as the type locality of the species (Pacheco \& Whitney 1997) where $T$. fasciatum had previously been deemed as probably extinct (Alves et al. 2000).

The specific habitat requirements of bird species such as T. fasciatum highlight the importance of riparian areas for the conservation of this and other riparian bird species. Therefore, this species is potentially threatened by the recently approved legislative reform to the Brazilian Forest Code (Código Florestal - Stickler et al. 2013), which authorized the reduction of the legally preserved strip width of riparian forests (Michalski et al. 2010). Thus, it is imperative to increase the scale and scope of research programs studying the distribution and ecology of T. fasciatum and other members of the Neotropical avifauna.

\section{Acknowledgements}

This research was supported by Conservation InternationalBrazil, the Walmart Institute-Brazil through the project "Support to the implementation of the National Forest of Amapá" and the Chico Mendes Institute for Biodiversity Conservation (ICMBio). The Federal University of Amapá (UNIFAP) provided logistical support. LNK and CMT were funded by a Brazilian Ministry of Education (CAPES) MSc student scholarship. We are thankful for the data provided by NatureServe in collaboration with Robert Ridgely, James Zook, The Nature Conservancy-Migratory Bird Program, Conservation International-CABS, World Wildlife Fund (US), and Environment Canada-WILDSPACE. Also, we are deeply indebted to Alvino Pantoja for field assistance, to Darren Norris for improvements of a previous English version, and to Luis Fabio Silveira and two anonymous referees for comments on the manuscript.

\section{References}

AGUIAR, K.M.O., NAIFF, R. \& XAVIER, B. 2010. Aves da Reserva Biológica do Lago Piratuba, Amapá, Brasil. Ornithologia 4(1):1-14. http:// www.cemave.net/publicacoes/index.php/ornithologia/article/view/47

AGUIAR, K.M.O. \& NAIFF, R.H. 2010. Composição da avifauna da Área de Proteção Ambiental do Rio Curiaú, Macapá, Amapá, Brasil. Ornithologia 4(1):36-48. http://cemave.net/ornithologia/index.php/ornithologia/article/ view/49.

ALVES, M.A.S., PACHECO, J.F., GONZAGA, L.A.P., CAVALCANTI, R.B., RAPOSO, M.A., YAMASHITA, C., MACIEL, N.C. \& CASTANHEIRA, M. 2000. Aves. In A Fauna Ameaçada de Extinção do Estado do Rio de Janeiro (H.G. Bergallo, C.F.D. Rocha, M.A.S. Alves \& M. Van Sluys, eds.). Editora UERJ, Rio de Janeiro, p.113-124.

ANDRADE, M.A. 1998. Tigrisoma fasciatum (Such, 1825). In Livro Vermelho das Espécies Ameaçadas de Extinção da Fauna de Minas Gerais (A.B.M. Machado, G.A.B. Fonseca, R.B. Machado, L.M.S. Aguiar \& L.V. Lins, eds.). Fundação Biodiversitas, Belo Horizonte, p.193-194.
BARNETT, A., SHAPLEY, R., BENJAMIN, P., HENRY, E. \& McGARRELL, M. 2002. Birds of the Potaro Plateau, with eight new species for Guyana. Cotinga 18(2002):19-36.

BECKER, C.D. \& LANÚS, B.L. 1997. Conservation value of a Garua forest in the dry season: a bird survey in Reserva Ecológica de Loma Alta, Ecuador. Cotinga 8:66-74. http://www.neotropicalbirdclub.org/articles/8/ C8-garua.pdf

BECKER, R. 2008. WA125881, Tigrisoma fasciatum (Such, 1825). Wiki Aves - A Enciclopédia das Aves do Brasil. http://www.wikiaves. com/125881 (último acesso em 28/06/2013).

BIRDLIFE, I. 2009. Species factsheet: Tigrisoma fasciatum. IUCN Red List of Threatened Species. version 2011.2, IUCN 2011. http://www.iucnredlist. org (último acesso em 24/06/2013).

BLANCO, D.E. 2013. WA945278, Tigrisoma fasciatum (Such, 1825). Wiki Aves - A Enciclopédia das Aves do Brasil. http://www.wikiaves. com/945278 (último acesso em 28/06/2013).

BLÁSQUEZ, J.R.E., COSTA-NETO, E.M. \& LANDERO-TORRES, I. 2009. Comparación de especies de abejas comestibles en la Sierra de Jibóia, (Bahia, Brasil) y Sierra de Zongolica (Veracruz, México). Rev. Colomb. Entomol. 35(2):217-223. http://www.scielo.org.co/pdf/rcen/ v35n2/v35n2a18.pdf.

BOSS, R.L. \& AGUIAR, K.M.O. 2011. Caracterização preliminar da avifauna em um trecho do rio Amapari, Serra do Navio, Amapá, Brasil. Ornithologia 4(2):110-125. http://cemave.net/ornithologia/index.php/ ornithologia/article/view/95.

CAVARETTO, R.C. 2011. WA506980, Tigrisoma fasciatum (Such, 1825). Wiki Aves - A Enciclopédia das Aves do Brasil. http://www.wikiaves. com/506980 (último acesso em 28/06/2013).

CINTRA, R. 2012. Ecological gradients influencing waterbird communities in black water lakes in the Anavilhanas Archipelago, Central Amazonia. Int. J. Ecol. 2012(1):1-21. http://dx.doi.org/10.1155/2012/801683

COLTRO, L.A. 2006. A avifauna da Floresta Nacional do Amapá registrada através de Inventários Biológicos Rápidos - expedição II e síntese do conhecimento para a unidade. In Inventários Biológicos Rápidos da Floresta Nacional do Amapá. IEPA, Macapá, p.42-56.

COLTRO, L.A. 2008. A avifauna do Parque Nacional Montanhas do Tumucumaque registrada durante o Projeto de Inventários Biológicos Rápidos. In RAP Bulletin of Biological Assessment (E. Bernard, eds.). Conservation International, Arlington, p.33-37.

CONSERVAÇÃO INTERNACIONAL DO BRASIL - CI-BRASIL. 2009. Corredor de Biodiversidade do Amapá. In Conservação Internacional, Belém, p.44.

EISENMANN, E. 1965. The tiger-herons (Tigrisoma) of Argentina. Hornero $10(3): 225-234$.

ESTELA, F.A. \& LÓPEZ-VICTORIA, M. 2005. Aves de la parte baja del Río Sinú, Caribe colombiano; inventario y ampliaciones de distribución. Bol. Invest. Mar. Cost. 34:7-42. http://www.scielo.org.co/scielo. php?pid=S0122-97612005000100001\&script=sci_arttext\&tlng=en.

FARIA, I.P. 2008. Duas novas ocorrências do socó-boi-escuro Tigrisoma fasciatum (Such, 1825) (Aves: Ardeidae) no Estado de Goiás, Brasil. Rev. Bras. Ornitol. 16(4):391-394.

FRAGA, R.M. 1996. Séccion III: Aves. In Libro rojo de mamíferos y aves amenazados de la Argentina (J.J. García Fernandez, R.A. Ojeda, R.M. Fraga, G.B. Díaz \& R.J. Baigún, eds.). Fundación para la Conservación de las Especies y el Medio Ambiente, Buenos Aires, p.155-219.

GARCIA, A.L. 2010. WA263696, Tigrisoma fasciatum (Such, 1825). Wiki Aves - A Enciclopédia das Aves do Brasil. http://www.wikiaves. com/263696 (último acesso em 28/06/2013).

INFONATURA. 2007. Tigrisoma fasciatum - Fasciated Tiger-Heron. Animals and Ecosystems of Latin America. version 5.0. Arlington, Virginia , NatureServe. http://www.natureserve.org/infonatura (último acesso em 24/06/2013).

LANE, D. 2010. Tigrisoma fasciatum. Neotropical Birds. http://neotropical. birds.cornell.edu/portal/species/overview?p_p_spp $=111836$ (último acesso em 28/06/2013). 
LÓPEZ, C. 2012. Herons (Ardeidae): Fasciated Tiger-heron (Tigrisoma fasciatum). http://ibc.lynxeds.com/photo/fasciated-tiger-herontigrisoma-fasciatum/adult-perched-tree-upright-posture (último acesso em 28/06/2013).

LÓPEZ-LANÚS, B., GRILLI, P., COCONIER, E., DI GIACOMO, A. \& BANCHS, R. 2008. Categorización de las aves de la Argentina según su estado de conservación. Informe de Aves Argentinas, AOP y Secretaría de Ambiente y Desarollo Sustentable. http://www.avesargentinas.org. ar/12/conservacion/Categorizacion $\% 20 \mathrm{de} \% 201$ as $\% 20$ Aves $\% 20 \mathrm{de} \% 20$ la\%20Argentina\%202008.pdf (último acesso em 20/06/2013).

MARTÍNEZ-VILALTA, F. \& MOTIS, A. 1992. Family Ardeidae (herons). In Handbook of the birds of the world (J. del Hoyo, A. Elliott \& J. Sargatal, eds.). Lynx Edicions, Barcelona, p.376-429.

MENEGHETI, J.O. 2008. Brasil: informe anual. Censo Neotropical de Aves Acuáticas 2007. In El Censo Neotropical de Aves Acuáticas 2007; Una herramienta para la conservación (D.A. Unterkofler \& D.E. Blanco, eds.). Wetlands International, Buenos Aires.

MICHALSKI, F., CONCEIÇÃO, P.C.F., AMADOR, J.A., LAUFER, J. \& NORRIS, D. 2012. Local perceptions and implications for giant otter (Pteronura brasiliensis) conservation around protected areas in the eastern Brazilian Amazon. IUCN Otter Spec. Group. Bull. 29:34-45.

MICHALSKI, F., NORRIS, D. \& PERES, C.A. 2010. No return from biodiversity loss. Science 329(1):1282. http://dx.doi.org/10.1126/ science.329.5997.1282-a

MISTRY, J., BERARDI, A. \& SIMPSON, M. 2008. Birds as indicators of wetland status and change in the North Rupununi, Guyana. Biodivers. Conserv. 17:2383-2409. http://dx.doi.org/10.1007/s10531-008-9388-2

OTTEMA, O. 2002. A possible population of Fasciated Tiger-heron Tigrisoma fasciatum on the upper Coppename, Surinam. Cotinga 18:103.

PACHECO, J.F. \& WHITNEY, B.M. 1997. On the Origin of Some Birds Collected by George Such, and the Type Localities of Several Forms. The Auk 114(2):303-305. http://dx.doi.org/10.2307/4089175

PAIVA, D.L. 2009. WA893215, Tigrisoma fasciatum (Such, 1825). Wiki Aves - A Enciclopédia das Aves do Brasil. http://www.wikiaves. com/893215 (último acesso em 28/06/2013).

PARKER III, T.A., STOTZ, D.F. \& FITZPATRICK, J.W. 1996. Ecological and distributional databases. In Neotropical birds: ecology and conservation (D.F. Stotz, J.W. Fitzpatrick, T.A. Parker \& D.K. Moskovits, eds.). University of Chicago Press, Chicago.

PERLO, B. 2009. A field guide to the birds of Brazil. Oxford University Press, New York.

PITMAN, N.C.A., NORRIS, D., GONZALEZ, J.M., TORRES, E., PINTO, F., COLLADO, H., CONCHA, W., THUPA, R., QUISPE, E., PÉREZ, J. \& DEL CASTILLO, J.C.F. 2011. Four years of vertebrate monitoring on an upper Amazonian river. Biodivers. Conserv. 20:827-849. http:// dx.doi.org/10.1007/s10531-010-9982-y

PIVATTO, M.A.C., MANÇO, D.G., STRAUBE, F.C., URBEN-FILHO, A. \& MILANO, M. 2006. Aves do Planalto da Bodoquena, Estado do Mato Grosso do Sul (Brasil). Atual. Ornitol. 129:1-26.
PRATOLONGO, F.A., TELLO, J.G. \& BARRIO, J. 2007. First records of Fasciated Tiger Heron Tigrisoma fasciatum in the west Peruvian Andes. Cotinga 29:173-175. http://www.corbidi.org/Investigacion/Publicaciones/ Angulo_EtAl_2008_FirstRecords.pdf

REIJNDERS, C. 2011. Herons (Ardeidae): Fasciated Tiger-heron (Tigrisoma fasciatum). http://ibc.lynxeds.com/node/121159 (último acesso em 28/06/2013).

RENAUDIER, A., CLAESSENS, O. \& DE GUYANE, C.H. 2010. Les oiseaux rares en Guyane en 2008 \& 2009. In Rapport du Comité d'homologation de Guyane, p.8.

RENAUDIER, A. \& DE GUYANE, C.H. 2010. Rare birds in French Guiana in 2005-07. Cotinga 32(2010):95-104. http://www.neotropicalbirdclub. org/articles/32/Renaudier.pdf

RIBOT, J.H. 2013. Checklist of birds of Suriname, South America. http:// www.surinamebirds.nl (último acesso em 24/06/2013).

RIDGELY, R.S., ALLNUTT, T.F., BROOKS, T., McNICOL, D.K., MEHLMAN, D.W., YOUNG, B.E. \& ZOOK, J.R. 2007. Digital Distribution Maps of the Birds of the Western Hemisphere. Version 3.0. NatureServe, Arlington, Virginia, USA. www.natureserve.org/getData/ birdMaps.jsp (último acesso em 24/06/2013).

SICK, H. 1997. Ornitologia brasileira. Editora Nova Fronteira, Rio de Janeiro.

SOITO, J.L.D. \& FREITAS, M.A.V. 2011. Amazon and the expansion of hydropower in Brazil: Vulnerability, impacts and possibilities for adaptation to global climate change. Renew. Sust. Energ. Rev. 15(6):31653177. http://dx.doi.org/10.1016/j.rser.2011.04.006

SOUZA, E.A.D., NUNES, M.F.C., ROOS, A.L. \& ARAUJO, H.F.P.D. 2008. Guia de campo: Aves do Parque Nacional do Cabo Orange. ICMBio/ Cemave, Amapá.

STICKLER, C.M., NEPSTAD, D.C., AZEVEDO, A.A. \& McGRATH, D.G. 2013. Defending public interests in private lands: compliance, costs and potential environmental consequences of the Brazilian Forest Code in Mato Grosso. Phil. Trans. R. Soc. B. 368:1-13. http://dx.doi.org/10.1098/ rstb.2012.0160

STRAUBE, F.C., OLMOS, F. \& CARRANO, E. 2008. Tigrisoma fasciatum. In Livro Vermelho da Fauna Brasileira Ameaçada de Extinção. Volume II. (A.B.M. Machado, G.M. Drummond \& A.P. Paglia, eds.). Ministério do Meio Ambiente, Brasília, p.418-420.

VALLELY, A.C., GALLARDO, R.J. \& ASCHER, J.S. 2010. Notes on the birds of the Río Plátano Biosphere Reserve, including four new species for Honduras. Bull. Br. Ornithol. Club. 130(1):52-60.

VOGT, C.A. 2007. Range extensions and noteworthy records for mainland Ecuador. Bull. Br. Ornithol. Club. 127(3):228-233. http://www. andeanbirding.com/assets/resources/research_rangeextensions.pdf.

WIKIAVES. 2013. Mapa de registros da espécie socó-boi-escuro (Tigrisoma fasciatum). http://www.wikiaves.com.br/mapaRegistros_soco-boi-escuro (último acesso em 28/06/2013).

YAMASHITA, C. \& VALLE, M.P. 1990. Ocorrência de duas aves raras no Brasil Central: Mergus octosetaceus e Tigrisoma fasciatum fasciatum. Ararajuba 1:107-109. 